\title{
PENERAPAN SISTEM INFORMASI AKUNTANSI DAN PENGENDALIAN INTERNAL TERHADAP KECURANGAN AKUNTANSI PADA BANK PERKREDITAN RAKYAT KOTA BATAM
}

\author{
Dian Efriyenty \\ Universitas Putera Batam
}

email : dianefriyenty@gmail.com

\begin{abstract}
The phenomenon associated with occurate of fraud in BPR is that it is closely related to the role of BPR internal control, which dosen not systematically oversee leadership in monitoring, evaluating and reporting all processes and stages of activities As in the case of an error at BPR Nusamba, one of the employees who collects savings and credit installments, must be deposited with client money but extortion occurs on BPR Nusamba cash, with the amount of money reaching Rp 115,429,909. The sample of this study was respondents who received authority in the use of funds in 27 BPR Batam City units. The results of the study stated that partially and simultaneously the application of accounting information systems and internal controls significantly influence accounting fraud.
\end{abstract}

Keywords: Application of Accounting Information Systems; Internal Control; Accounting Fraud

\section{PENDAHULUAN}

Bank Perkreditan Rakyat (BPR) adalah bank yang melakukan kegiatan usaha secara konvensional atau syariah, yang dalam kegiatannya tidak memberikan layanan dalam lalu lintas pembayaran. Fungsi utama BPR adalah untuk menyediakan kredit investasi dan pinjaman eksploitasi dalam skala kecil dengan jaminan kepada orang-orang di daerah tersebut (Sujatmoko, 2015, p. 28).

Fenomena terkait dengan terjadinya kecurangan dalam BPR terkait erat dengan peran pengendalian internal BPR, yang tidak secara sistematis mengawasi kepemimpinan dalam memantau, mengevaluasi dan melaporkan semua proses dan tahapan kegiatan. Seperti dalam kasus kesalahan pencatatan uang di BPR Nusamba, di mana salah satu karyawan yang mengumpulkan angsuran tabungan dan kredit, harus disetor dengan uang klien namun terjadi pemerasan pada uang tunai BPR Nusamba, jumlah uang sejak November 2014 hingga Mei 2015 mencapai Rp 115.429.909 (Pemerintah kota Yogyakarta, 2015). Kegiatan penipuan dapat dikurangi dengan adanya sistem kontrol internal dan pemantauan oleh atasan.

Kasus lain terjadi pada Oktober 2014, dugaan kasus korupsi Rp. 20 miliar di Bank Perkreditan Rakyat Aceh Utara (BPR) Sabee Meusampe, berasal dari Anggaran Pendapatan Belanja Kabupaten 2017. Seperti diketahui, Rp. 20 miliar Dana Pemberdayaan Ekonomi Bank untuk penduduk. Namun distribusinya tidak sesuai dengan keputusan Pemerintah Daerah. Kerugian ini berasal dari dana kredit fiktif Pemerintah Kabupaten Aceh Utara (Bahri, 2019). Penipuan ini terjadi karena sistem kontrol internal yang rendah dan kurangnya skandal penipuan akuntansi di Indonesia. Hal ini terbukti dari likuidasi beberapa bank, yang diajukan oleh Badan Usaha Milik Negara dan Swasta, sehingga keberadaan kejahatan bank dan manipulasi pajak semakin meningkat.

Fenomena terkait dengan terjadinya kecurangan dalam BPR terkait erat dengan peran pengendalian internal BPR, yang tidak secara sistematis mengawasi kepemimpinan dalam memantau, mengevaluasi dan melaporkan semua proses dan tahapan kegiatan. Seperti dalam kasus kesalahan pencatatan uang di BPR Nusamba, di mana salah satu karyawan yang 
mengumpulkan angsuran tabungan dan kredit, harus disetor dengan uang klien namun terjadi pemerasan pada uang tunai BPR Nusamba, jumlah uang sejak November 2014 hingga Mei 2015 mencapai Rp 115.429.909 (Pemerintah kota Yogyakarta, 2015). Kegiatan penipuan dapat dikurangi dengan adanya sistem kontrol internal dan pemantauan oleh atasan. Kerugian ini berasal dari dana kredit fiktif Pemerintah Kabupaten Aceh Utara (Bahri, 2019). Penipuan ini terjadi karena sistem kontrol internal yang rendah dan kurangnya skandal penipuan akuntansi di Indonesia. Hal ini terbukti dari likuidasi beberapa bank, yang diajukan oleh Badan Usaha Milik Negara dan Swasta, sehingga keberadaan kejahatan bank dan manipulasi pajak semakin meningkat.

\section{TINJAUAN PUSTAKA}

\section{Kecurangan Akuntansi}

Association of certified fraud (ACFE) mendefinisikan kecurangan akuntansi sebagai tindakan kecurangan atau dikenal oleh seseorang atau entitas yang mengetahui kesalahan dapat menyebabkan manfaat yang tidak baik bagi orang lain (Accountant \& Examiners, 2015, p. 87).

\section{Penerapan Sistem Informasi Akuntansi}

Sistem Informasi Akuntansi menurut (Jogiyanto, 2015, p. 67), sistem informasi akuntansi adalah kumpulan kegiatan organisasi yang bertanggung jawab untuk menyediakan informasi keuangan dan informasi yang diperoleh dari data transaksi untuk pelaporan internal kepada manajer untuk digunakan dalam kontrol dan perencanaan, baik sekarang dan operasi masa depan dan pelaporan eksternal kepada pemegang saham, pemerintah dan pihak eksternal lainnya.

Pengendalian Internal

Menurut (Krismiaji, 2015, p. 45) pengendalian internal adalah rencana dan metode organisasi yang digunakan untuk melindungi aset, memberikan informasi yang akurat dan dapat diandalkan, meningkatkan efisiensi dan mendorong kepatuhan dengan kebijakan manajemen.

\section{Hipotesis Penelitian}

Berdasarkan landasan teori dan penelitian terdahulu maka hipotesis yang diajukan dalam penelitian ini sebagai berikut :

1. Penerapan sistem informasi akuntansi berpengaruh terhadap kecurangan akuntansi

2. Pengendalian internal berpengaruh terhadap kecurangan akuntansi

3. Penerapan sistem informasi akuntansi dan pengendalian internal berpengaruh terhadap kecurangan akuntansi.

\section{METODE}

Populasi dan Sampel

Populasi dalam penelitian ini adalah semua pihak yang menerima wewenang dan tanggung jawab untuk terlibat dalam penggunaan dana yang dianggarkan yaitu pimpinan direktur, manajemen perbankan serta internal kontrol yang termasuk pelaksana akuntansi dan karyawan yang memungkinkan dapat melakukan kecurangan yang terjadi pada BPR Kota Batam. Berdasarkan data di atas bahwa total populasi adalah 27 unit BPR di kota Batam. Sedangkan sampel adalah bagian dari karakteristik populasi. Dalam penelitian ini menggunakan teknik sampling jenuh. Metode pengukuran untuk proses produksi adalah penggunaan semua anggota populasi sebagai sampel (Sugiyono, 2015). Karena populasinya relatif sedikit maka, semua sampel yang digunakan dalam penelitian ini adalah 27 unit BPR. 
Teknik Pengumpulan Data

Teknik pengumpulan data dalam penelitian ini adalah dengan menggunakan angket kepada responden dengan harapan menanggapi item pernyataan. Dalam penelitian ini memakai cara, observasi, kuesioner dan wawancara terkait dengan jumlah BPR di kota Batam serta pengendalian internal menggunakan sistem informasi akuntansi dan kecurangan akuntansi yang terjadi di BPR Kota Batam.

Variabel Penelitian

Definisi operasional variabel adalah penentuan variabel sehingga menjadi variabel yang dapat diukur. Variabel penelitian didalam penelitian ini terlihat sebagai berikut:

Kecurangan Akuntansi (Y)

Kecerdasan manusia didorong oleh satu individu untuk menciptakan manfaat dari pihak lain (Albert \& Sukirno, 2015, p. 20).

Indikator kecurangan akuntansi pada (Wilopo, 2016, p. 15):

a. Kecenderungan untuk memanipulasi, memalsukan, atau mengubah catatan akuntansi.

b. Kecenderungan untuk membuat penyajian yang keliru atau kegagalan dari peristiwa signifikan atau transaksi informasi dari laporan keuangan.

c. Kecenderungan untuk secara sengaja menerapkan prinsip akuntansi.

d. Kecenderungan untuk membuat laporan keuangan yang salah karena pencurian aset yang dibayar entitas untuk barang atau jasa yang tidak diterima.

e. Kecenderungan untuk menyajikan laporan keuangan palsu karena perlakuan yang tidak tepat disertai dengan dokumen palsu.

Penerapan Sistem Informasi Akuntansi (X1)

Adalah Pengumpulan sumber daya yang dirancang untuk menyediakan data

pengambilan keputusan sesuai dengan integritas dan otoritas (Jumaili \& Salman, 2015, p. 121). Penelitian ini mengukur variabel implementasi sistem informasi akuntansi berdasarkan tiga subsistem (Bondar, George, \& William, 2016, p. 54), yaitu sistem pemprosesan transaksi, buku besar atau sistem pelaporan keuangan, sistem pelaporan manajemen.

Pengendalian Internal (X2)

Adalah Salah satu kontrol perencanaan dalam perusahaan (Perbankan, 2017, p. 57). Adapun indikatornya menurut (Mulyadi, 2016, p. 76):
a. Lingkungan kontrol
b. Penilaian risiko
c. Kegiatan manajemen
d. Informasi dan komunikasi
e. Pemantauan

Analisis Data

Teknik analisis data yang digunakan dalam penelitian ini antara lain menguji kualitas data dengan menguji validitas data dan uji reliabilitas data, pengujian asumsi klasik kemudian dilanjutkan dengan berbagai analisis regresi yaitu dilakukan uji statistic deskriptif, uji asumsi klasikyang terdiri dari uji validitas dan reabilitas data, uji normalitas data, uji heterokedasitas, uji multikoliearitas dan uji autokorelasi, serta dilakukan pengujian uji $t$ dan uji $f$ untuk menjawab hasil hipotesis.

Analisis regresi berganda digunakan dalam penelitian ini untuk melihat pengaruh varabel independen terhadap variable dependen. Dengan demikian, variabel kecurangan akuntansi diterangkan oleh variable penerapan sistem informasi akuntansi dan pengendalian internal. Sehingga bisa dirumuskan dengan persamaan berikut: 


$$
\mathrm{Y}=\boldsymbol{\beta 0}+\boldsymbol{\beta} 1 \mathrm{X} 1+\beta 2 \mathrm{X} 2+\mathrm{e}
$$

\section{Rumus 3. 1 Regresi Berganda}

Dimana :

Y : Kecurangan akuntansi

$\mathrm{X} 1$ : Penerapan sistem informasi akuntansi

$\mathrm{X} 2$ : Pengendalian internal

$\beta 0$ : Konstanta

$\beta 1 \beta 2 \beta 3$ :Koefisien Regresi

e : standard error

\section{HASIL DAN PEMBAHASAN}

\section{Isi Hasil dan Pembahasan}

Objek dalam penelitian ini adalah 27 unit BPR yang terdaftar di Otoritas Jasa Keuangan yang ditujukan kepada pimpinan direktur, manajemen perbankan serta internal kontrol yang termasuk pelaksana akuntansi. Perwakilan pada masing-masing BPR berjumlah 3 orang, sehingga dilakukan pengolahan untuk 27 data. Setelah data terkumpul, data diolah menggunakan IBM SPSS (Statistical Package For Social Science) Versi 24.

Uji Validitas dan Reabilitas Data

Uji Validitas Data

Item kuesioner dinyatakan valid apabila nilai r-hitung > r-tabel. Berikut ini hasil uji validitas data:

Tabel 1. Hasil Uji Validitas

\begin{tabular}{|l|l|l|l|l|}
\hline \multicolumn{1}{|c|}{ Variabel } & Item & $\mathbf{r}_{\text {hitung }}$ & $\mathbf{r}_{\text {tabel }}$ & Kesimpulan \\
\hline \multirow{4}{*}{$\begin{array}{l}\text { Penggunaan } \\
\text { informasi akuntansi } \\
\text { (Y) }\end{array}$} & Y_1 & 0,261 & 0,2185 & Valid \\
\cline { 2 - 5 } & Y_2 & 0,391 & 0,2185 & Valid \\
\cline { 2 - 5 } & Y_3 & 0,235 & 0,2185 & Valid \\
\cline { 2 - 5 } & Y_4 & 0,523 & 0,2185 & Valid \\
\cline { 2 - 5 } & Y_5 & 0,567 & 0,2185 & Valid \\
\hline
\end{tabular}




\begin{tabular}{|l|l|l|l|l|}
\hline & X1_1 & 0,544 & 0,2185 & Valid \\
\cline { 2 - 5 } & $\mathrm{X} 1.2$ & 0,615 & 0,2185 & Valid \\
\cline { 2 - 5 } $\begin{array}{l}\text { X1 Pistem Informas } \\
\text { Akuntansi }\end{array}$ & $\mathrm{X} 1.3$ & 0,464 & 0,2185 & Valid \\
\cline { 2 - 5 } & $\mathrm{X} 1.4$ & 0,454 & 0,2185 & Valid \\
\hline \multirow{4}{*}{$\begin{array}{l}\text { X2 Pengendalian } \\
\text { Internal }\end{array}$} & $\mathrm{X} 2 \_1$ & 0,695 & 0,2185 & Valid \\
\cline { 2 - 5 } & $\mathrm{X} 2.2$ & 0,602 & 0,2185 & Valid \\
\cline { 2 - 5 } & $\mathrm{X} 2.4$ & 0,556 & 0,2185 & Valid \\
\cline { 2 - 5 } & $\mathrm{X} 2.5$ & 0,641 & 0,2185 & Valid \\
\cline { 2 - 5 } & $\mathrm{X} 2.6$ & 0,343 & 0,2185 & Valid \\
\hline
\end{tabular}

\section{Sumber: Data diolah, SPSS 2,, 2019}

Terlihat bahwa korelasi antara masing-masing indikator terhadap total skor konstruk dari setiap variabel menunjukkan hasil yang signifikan, dan menunjukkan bahwa r-hitung > rtabel. Dengan melihat $r$-table dengan jumlah sampel 81 diperoleh $r$ table menggunakan rumus: $\mathrm{df}=\mathrm{n}-2$, maka hasilnya sebesar 0,2185 . Sehingga dapat disimpulkan bahwa semua item pertanyaan dinyatakan valid.

Hasil Uji Reliabilitas berikut ini:

Hasil pengujian reliabilitas untuk masing-masing variabel yang diringkas pada tabel 2

Tabel 2 Hasil Uji Realibilitas

\begin{tabular}{|l|l|l|}
\hline Variabel & $\begin{array}{l}\text { Cronbach's } \\
\text { Alpha }\end{array}$ & Kesimpulan \\
\hline Penerapan sistem informasi akuntansi (X1) & 0,646 & Reliabel \\
\hline Pengendalian internal (X2) & 0,642 & Reliabel \\
\hline Kecurangan akuntansi (Y) & 0,514 & Reliabel \\
\hline
\end{tabular}

\section{Sumber : Data diolah, SPSS 24, 2019}

Hasil uji reliabilitas tersebut menunjukkan bahwa semua variabel mempunyai koefisien Cronbach's Alpha yang cukup besar yaitu diatas 0,60. Nilai Cronbach's Alpha untuk variabel penerapan sistem informasi akuntansi sebesar 0,646 dan untuk variabel pengendalian internal sebesar 0,642 dan variabel kecurangan akuntansi sebesar 0,514. Nilai cronbach Alpha diatas 0,60 sedangkan nilai $r$ kritis (uji 2 sisi) pada signifikansi 0,05 dengan jumlah data $(n)=81$, didapatkan nilai $r$ tabel karena $r$ hitung lebih besar dari $r$ tabel 0,2185 maka dapat disimpulkan bahwa butir-butir pertanyaan penelitian tersebut reliable.

\section{Uji Asumsi Klasik}




\section{Uji Normalitas Data}

Untuk menguji normalitas data pada penelitian ini menggunakan uji Kolmogrov-Smirnov test. Dimana hasil pengujiannya menunjukkan data berdistribusi normal. Seperti yang ditunjukkan oleh tabel 3 dibawah ini:

Tabel 3 Hasil Uji Normalitas

\begin{tabular}{|c|c|c|}
\hline & & $\begin{array}{l}\text { Standardized } \\
\text { Residual }\end{array}$ \\
\hline $\begin{array}{l}\text { N } \\
\text { Normal Parameters } \\
\text { Most } \\
\text { Differences } \\
\text { Test Statistic } \\
\text { Asymp. Sig. (2-tailed) }\end{array}$ & $\begin{array}{l}\text { Mean } \\
\text { Std. Deviation } \\
\text { Absolute } \\
\text { Positive } \\
\text { Negative }\end{array}$ & $\begin{array}{l}81 \\
, 0000000 \\
, 98742088 \\
, 098 \\
, 098 \\
-, 055 \\
, 098 \\
, 063^{\mathrm{c}}\end{array}$ \\
\hline
\end{tabular}

Sumber : Data diolah, SPSS 24, 2019

Menganalisis nilai kolmogorov-smirnov di atas bisa diambil kesimpulan bahwa, data memiliki distribusi normal karena nilai kolmogorov-smirnov memiliki tingkat signifikan 0,063 $>0,05$.

\section{Uji Multikolinearitas}

Berdasarkan table output yang telah diolah oleh SPSS 24 yang melibatkan variable dependent maka dihasilkan table colinierity sebagai berikut:

Tabel 4. Hasil Uji Multikolinearitas

\begin{tabular}{|l|l|l|l|}
\hline \multicolumn{2}{|l|}{ Model } & \multicolumn{2}{l|}{ Collinearity Statistics } \\
\cline { 3 - 4 } & Tolerance & VIF \\
\hline 1 & $\begin{array}{l}\text { Total_X1PenerapaSistemI } \\
\text { nformasiAkuntansi }\end{array}$ &, 993 & 1,007 \\
\cline { 2 - 4 } & $\begin{array}{l}\text { Total_X2PengendalianInt } \\
\text { ernal }\end{array}$ &, 993 & 1,007 \\
\hline
\end{tabular}

Sumber : Data diolah, SPSS 24, 2019

Berdasarkan hasil perhitungan diatas tampak bahwa VIF dari masing-masing variabel yaitu $\mathrm{X}_{1}=1,007$ dan $\mathrm{X}_{2}=1,007$ berada di bawah angka 10 . Dengan demikian bahwa model tersebut tidak memiliki gejala multikolinieritas atau bebas multikolinieritas. 


\section{Uji Heterokedasitas}

Berikut adalah hasil dari uji heteroskedastisitas pada tabel 5 dibawah ini.

Tabel 5. Hasil Uji Heterokedasitas

\begin{tabular}{|c|c|c|c|c|c|c|}
\hline \multirow{2}{*}{\multicolumn{2}{|c|}{ Model }} & \multicolumn{2}{|c|}{$\begin{array}{l}\text { Unstandardized } \\
\text { Coefficients }\end{array}$} & \multirow{2}{*}{\begin{tabular}{|l} 
Standardized \\
Coefficients
\end{tabular}} & \multirow[b]{2}{*}{$\mathrm{T}$} & \multirow[b]{2}{*}{ Sig. } \\
\hline & & B & Std. Error & & & \\
\hline \multirow[t]{6}{*}{1} & (Constant) & $1,316 \mathrm{E}-15$ & 4,445 & & ,000 & 1,000 \\
\hline & Total_X1Pe & & & & & \\
\hline & $\begin{array}{l}\text { nerapaSiste } \\
\text { mInformasi }\end{array}$ &, 000 &, 166 &, 000 & ,000 & 1,000 \\
\hline & Akuntansi & & & & & \\
\hline & Total_X2Pe & & & & & \\
\hline & $\begin{array}{l}\text { ngendalianI } \\
\text { nternal }\end{array}$ & ,000 &, 147 & ,000 & ,000 & 1,000 \\
\hline
\end{tabular}

Sumber : Data diolah, SPSS 24, 2019

Dari hasil output diketahui bahwa korelasi antara X1_penerapan sistem informasi akuntansi dan $\mathrm{X} 2$ _pengendalian internal dengan nilai signifikansi 1.000 ketiga nilai tersebut lebih besar dari 0,05, maka ditarik kesimpulan bahwa model penelitian ini tidak mengalami masalah heterokedasitas.

\section{Uji Autokorelasi}

Berikut merupakan hasil uji autokorelasi yang terlihat pada tabel 6 dibawah ini.

Tabel 6. Hasil Uji Autokorelasi

\begin{tabular}{|l|c|l|l|l|l|}
\hline Model & $\mathrm{R}$ & $\mathrm{R}$ Square & $\begin{array}{l}\text { Adjusted } \\
\text { Square }\end{array}$ & $\begin{array}{l}\text { Std. Error of } \\
\text { the Estimate }\end{array}$ & $\begin{array}{l}\text { Durbin- } \\
\text { Watson }\end{array}$ \\
\hline 1 &, $159^{\mathrm{a}}$ &, 025 &, 000 & 1,47466 &, 930 \\
\hline
\end{tabular}

Sumber : Data diolah, SPSS 24, 2019

Berdasarkan hasil perhitungan diatas bahwa nilai $\mathrm{DW}=0,930>0,05$ maka dapat dikatakan tidak terjadi autokorelasi. Secara sederhana dapat dikatakan bahwa suatu model dapat dikatakan tidak terjadi gejala autokorelasi, jika probabilitas nilai Durbin-Watson >0,05. Pada tabel di atas probabilitas nilai Durbin Watson adalah 0,930>0,05, maka dapat dipastikan bahwa model tersebut tidak mengalami gejala autokorelasi.

\section{Hasil dan Pembahasan Uji Hipotesis}

Hasil pengujian hipotesis dari uji t, dan uji $\mathrm{F}$ dapat dilihat pada tabel dibawah ini:

\section{Uji t}

Berdasarkan hasil uji t dibawah bahwa semua hasil mengalami signifkansi yang lebih kecil dari 0,05 . 
Tabel 8. Hasil Uji t

\begin{tabular}{|c|c|c|c|c|c|}
\hline \multirow[b]{2}{*}{ Model } & \multicolumn{2}{|c|}{$\begin{array}{l}\text { Unstandardized } \\
\text { Coefficients }\end{array}$} & \multirow{2}{*}{$\begin{array}{l}\text { Standardize } \\
\mathrm{d} \\
\text { Coefficients } \\
\text { Beta }\end{array}$} & \multirow[b]{2}{*}{$\mathrm{t}$} & \multirow[b]{2}{*}{ Sig. } \\
\hline & B & Std. Error & & & \\
\hline 1 (Constant) & 22,825 & 4,445 & & 5,135 & ,000 \\
\hline $\begin{array}{l}\text { Total_X1Penera } \\
\text { paSistemInforma } \\
\text { siAkuntansi }\end{array}$ & 234 &, 166 & 3,006 & 2,414 & ,001 \\
\hline $\begin{array}{l}\text { Total_X2Pengen } \\
\text { dalianInternal }\end{array}$ & ,002 &, 147 & 3,012 & 2,012 & ,000 \\
\hline
\end{tabular}

Sumber : Data diolah, SPSS 24, 2019

\section{Uji F}

Pengujian ini dilakukan untuk mengetahui semua variabel independen $\left(X_{1}, X_{2}\right)$ yang dimasukkan dalam model memiliki pengaruh secara bersama-sama terhadap variabel dependen.

Tabel 9. Hasil Uji F (Simultan)

\begin{tabular}{|l|r|r|l|l|l|}
\hline Model & \multicolumn{1}{|l|}{$\begin{array}{l}\text { Sum of } \\
\text { Squares }\end{array}$} & Df & Mean Square & F & Sig. \\
\hline 1 Regression & 4,380 & 2 & 2,190 & 3,207 &, $000^{\mathrm{b}}$ \\
Residual & 169,620 & 78 & 2,175 & & \\
Total & 174,000 & 80 & & & \\
\hline
\end{tabular}

\section{Sumber : Data diolah, SPSS 24, 2019}

Berdasarkan tabel perhitungan diatas diperoleh nilai Fhitung dibandingkan dengan Ftabel $(3,207>3,11)$ dan nilai signifikan $0,000<0,05$ yang menunjukkan bahwa H3 diterima. Nilai $F_{\text {hitung }}>$ dari $F_{\text {tabel }}$ sehingga $\mathrm{H} 3$ juga diterima menunjukkan bahwa secara simultan penerapan sistem informasi akuntansi dan pengendalian internal berpengaruh secara signifikan terhadap kecurangan akuntansi (Y).

Berdasarkan hasil uji t dan uji f pembahasannya adalah sebagai berikut:

Penerapan Sistem Informasi Akuntansi Berpengaruh Terhadap Kecurangan Akuntansi

Berdasarkan hasil penelitian untuk $\mathrm{t}_{\text {hitung }}(2,414)>\mathrm{t}_{\text {tabel }}(1,990)$ dan nilai signifikan $0,001<0,05$. Jadi dapat dikatakan penerapan sistem informasi akuntansi $\left(\mathrm{X}_{1}\right)$ berpengaruh signifikan terhadap kecurangan akuntansi (Y) pada Bank Perkreditan Rakyat kota Batam, sehingga hipotesis pertama diterima. Artinya, penerapan sistem informasi akuantansi berpengaruh signifikan terhadap kecurangan akuntansi. 
Penerapan sistem informasi akuntansi entitas secara signifikan dapat memberikan pengaruh timbulnya risiko salah saji material dalam laporan keuangan. Hasil penelitian ini sejalan dengan penelitian yang menyatakan (Claudia, 2017) melakukan penelitian tentang dampak teknologi informasi akuntansi dalam pengendalian internal untuk mengantisipasi kecurangan akuntansi.

Pengendalian Internal Berpengaruh Terhadap Kecurangan Akuntansi

Berdasarkan hasil penelitian untuk $\mathrm{t}_{\text {hitung }}(2,012)>\mathrm{t}_{\text {tabel }}(1,990)$ dan nilai Signifikan $0,000<0,05$. Jadi pengendalian internal $\left(\mathrm{X}_{2}\right)$ berpengaruh signifikan terhadap kecurangan akuntansi (Y) pada Bank Perkreditan Rakyat Batam, sehingga hipotesis kedua diterima. Dengan demikian semakin tinggi penggunaan pengendalian internal akan semakin berkurang pula kecurangan akuntansi pada BPR Kota Batam. Hasil penelitian ini konsisten dengan hasil penelitian yang dilakukan oleh (Wilopo, 2016) melakukan penelitian tentang pengaruh pengendalian intenal terhadap kecurangan akuntansi di Badan Pengawas Keuangan (BPK).

Penerapan Sistem Informasi Akuntansi dan Pengendalian Internal Berpengaruh Terhadap Kecurangan Akuntansi

Berdasarkan hasil penelitian nilai Fhitung dibandingkan dengan Ftabel $(3,207>3,11)$ dan nilai signifikan $0,000<0,05$ yang menunjukkan bahwa $\mathrm{H} 3$ diterima. Nilai $\mathrm{f}_{\text {hitung }}>$ dari $\mathrm{f}_{\text {tabel }}$ dan signifikansi lebih kecil dari 0,05 , sehingga $\mathrm{H}_{3}$ juga diterima yang menunjukkan bahwa secara simultan sistem informasi akuntansi dan pengendalian internal berpengaruh secara signifikan terhadap kecurangan akuntansi (Y) pada Bank Perkreditan Rakyat Kota Batam. Sistem informasi akuntansi dibuat untuk memberikan informasi keuangan yang dibutuhkan oleh manajemen sebuah perusahaan guna memudahkan pengelolaan perusahaan, namun penerapan sistem informasi akuntansi tidak lepas dari adanya risiko keamanan dan salah saji yang dapat terjadi secara disengaja maupun tidak disengaja. Hasil penelitian ini sejalan dengan penelitian (Animah, 2018) dengan judul penelitiannya pengaruh sistem informasi akuntansi dan efektivitas pengendalian internal terhadap kecurangan akuntansi di BPR Aceh yang menyatakan bahwa penerapan sistem informasi akuntansi dan efektivitas pengendalian internal berpengaruh simultan terhadap kecurangan akuntansi.

\section{SIMPULAN}

Berdasarkan hasil penelitian dan pembahasan yang telah diuraikan, maka penulis menarik kesimpulan adalah sebagai berikut:

1. Pengaruh sistem informasi akuntansi $\left(X_{1}\right.$ untuk $t_{\text {hitung }}(2,414)>t$ tabel $(1,990)$ dan nilai signifikan $0,001<0,05$. Jadi sistem informasi akuntansi $\left(\mathrm{X}_{1}\right)$ berpengaruh signifikan terhadap kecurangan akuntansi (Y).

2. Pengaruh pengendalian internal $\left(\mathrm{X}_{2}\right)$ terhadap kecurangan akuntansi $(\mathrm{Y})$. Hasil perhitungan untuk $t_{\text {hitung }}(2,012)>t_{\text {tabel }}(1,990)$ dan nilai signifikan $0,000<0,05$. Jadi pengendalian internal $\left(\mathrm{X}_{2}\right)$ berpengaruh signifikan terhadap kecurangan akuntansi (Y).

3. Pengaruh Fhitung dengan Ftabel $(3,207>3,11)$ dan nilai signifikan $0,000<0,05$ yang menunjukkan bahwa H3 diterima. Maka secara simultan penerapan sistem informasi akuntansi dan pengendalian internal berpengaruh secara signifikan terhadap kecurangan akuntansi (Y). 


\section{SARAN}

Berdasarkan hasil penelitian penulis mengusulkan saran-saran yang kiranya bermanfaat bagi pihak-pihak yang terkait dalam penelitian yaitu :

1. Saran akademisi, variabel yang digunakan dalam penelitian ini masih sangat terbatas. Oleh karena itu, peneliti selanjutnya dapat memperluas penelitian tentang fraud dengan menambah variabel lainnya sehingga menghasilkan penelitian yang lebih baik dari penelitian sebelumnya serta jumlah sampel yang digunakan dapat diperbanyak dan diperluas.

2. Saran praktis, diharapkan para manajemen di BPR Kota Batam, dalam menurunkan fraud, agar dapat memperhatikan kearah yang lebih baik lagi mengenai kesesuaian kompensasi, penerapan sistem informasi akuntansi dan efektivitas pengendalian internal sangat berperan dalam membantu manajemen dan para karyawan yang bertanggung jawab dalam pelaksanaan aktivitas-aktivitas perencanaan, pengorganisasian dan pengawasan.

\section{DAFTAR PUSTAKA}

Accountant, A. I. of C. P., \& Examiners, A. of C. F. Managing The Business Risk Of Fraud: A Practical Guide (2015).

Albert, \& Sukirno. (2015). Pengaruh Pengendalian Intern, Kepatuhan dan Kompensasi Manajemen Terhadap Perilaku Etis Karyawan. Jurnal Nominal, 2(5), 17-26. https://doi.org/ISSN: 2502-5430

Animah. (2018). pengaruh sistem informasi akuntansi dan efektivitas pengendalian internal terhadap kecurangan akuntansi. Jurnal Akuntansi Dan Manajemen, 4(8), 168-183-1270.

Anne, B., Scott, L. H., \& Helen, Z. (2019). The effect of banks financial reporting on syndicated-loan structures. Journal of Accounting and Economics, 1(3), 33-42. https://doi.org/https://doi.org/10.1016/j.jacceco.2019.01.002Get rights and content

Bondar, George, \& William. (2016). Accounting Information System (Seven Edit). USA.

Claudia. (2017). Dampak teknologi informasi dalam pengendalian internal untuk mengatisipasi kecenderungan kecurangan akuntansi. Jurnal Riset Akuntansi Going Concern, 9(7), 1-99737.

Ghozali. (2016). Aplikasi Analisis Multivariate Dengan Program IBM SPSS 23 (Edisi Dela). Semarang: Universitas Diponogoro.

Jogiyanto. (2015). Analisis Sistem Informasi Akuntansi. Yogyakarta: Andi offset.

Jumaili, \& Salman. (2015). Kepercayaan terhadap teknologi sistem informasi baru dalam evaluasi kinerja individual. Jurnal Akuntansi, Ekonomi Dan Manajemen Bisnis, 5(4), $118-127$.

Krismiaji. (2015). Sistem Informasi Akuntansi. Yogyakarta: AMP: YKPN.

Mulyadi. (2016). Auditing (Buku I Edi). Jakarta: Salemba Empat.

Pemerintah kota yogyakarta. (2015). peran pengndalian BPR. Retrieved from http://lokalzone.com/2015/01

Perbankan, I. B. (2017). Mengenal Operasional Perbankan. Gramedia Pustaka Utama.

Sugiyono. (2015). Metode Penelitian Kuantitatif, Kualitatif, R Dan D. Bandung: Alfabeta.

Sujatmoko, E. (2015). Akuntansi Perbankan (Edisi 1). Andi offset.

Wibowo, A. E. (2012). Aplikasi Praktis SPSS Dalam Penelitian (Cetakan 1). Yogyakarta: BPFE Universitas Diponegoro.

Wilopo. (2016). Analisis faktor-faktor yang berpengaruh terhadap kecenderungan kecurangan akuntansi: studi pada perusahaan publik dan badan. Jurnal Akuntansi Dan Manajemen, 2(4), 11-18. https://doi.org/ISSN: 1829-9857 